Dr BOJAN B. DIMITRIJEVIĆ, naučni savetnik

Institut za savremenu istoriju

Beograd, Trg Nikole Pašića 11

\title{
EPOHA POMERANJA ISTORIOGRAFSKIH SAZNANJA I OPTUŽBE ZA „REVIZIONIZAM"**
}

U Srbiji se od početka devedesetih godina moglo u principu slobodno pisati o događajima iz bliske prošlosti, a posebno Drugog svetskog rata. Ovo interesovanje je pre svega objašnjivo uticajem podele u srpskom društvu na "partizane“ i „četnike“. Ova podela dobila je i svoje dnevnopolitičke aktere u Srbiji tokom devedesetih godina i dodatno pojačala antagonizme i stereotipe.

Pojedine naše kolege, pa i autor ovih redova, od sredine 1990-ih na ovamo najviše su se bavili istorijom Ravnogorskog pokreta, Jugoslovenskom vojskom u Otadžbini, generalom Mihailovićem i drugim pitanjima vezanim za „četničku“ stranu istorije Drugog svetskog rata u Srbiji i Jugoslaviji. Ovaj segment je varirao od monografija opšteg tipa i sveobuhvatnog pogleda na srpski i jugoslovenski prostor, preko zbirki dokumenata, sve do lokalnih studija pojedinih oblasti. Interesovanje za ovu temu ostalo je aktuelno i u inostranoj istoriografiji, pa je u proteklih dve decenije objavljeno nekoliko značajnih studija na engleskom, francuskom i nemačkom jeziku. Valja pomenuti da je deo saznanja o ovim temama u Srbiju stigao kroz reizdanja publicističkih dela iz srpske emigracije. Obilna je bila i srpska publicistika, mada je pojedinim delima doprinela konfuziji i pojednostavljenom, katkad i iskrivljenom pogledu na događaje iz rata.

Tako je od početka 1990-ih srpska istoriografija ponudila nova tumačenja događaja $\mathrm{u}$ okupiranoj Jugoslaviji i Srbiji: istorije Srbije pod okupacijom, istorije Ravnogorskog pokreta, Jugoslovenske vojske u Otadžbini na nivou Srbije i pojedinih okruga ili oblasti (Valjevo, Čačak, ove godine i Smederevo, itd.), vojske Nedićeve Srbije, biografije generala Mihailovića, srpskog ustanka u junu 1941, događaja u NDH, odnosa prema okupatoru, propagande, svakodnevnog života pod okupacijom i drugih

Rad je deo projekta Srpsko društvo u jugoslovenskoj državi u 20. veku: između demokratije i diktature (177016) koji finansira Ministarstvo prosvete, nauke i tehnološkog razvoja Republike Srbije. 
pitanja. Protumačeno je postojanje pojedinih logora kao što su Jasenovac, Sajmište, Banjica i drugi. Utvrđene su brojke stradalih u njima, kao i nadležnost nad tim logorima.

U prošloj deceniji otvoreno je pitanje partizanskih zločina posle ulaska u Srbiju, masovnih likvidacija i političke represije u Titovoj Jugoslaviji, posebno u prvoj deceniji posle Drugog svetskog rata.

Bitno je istaći da je najveći deo ovih radova imao svoju školsku i zanatsku verifikaciju na Beogradskom univerzitetu, jer je reč o naučnim radovima i sa mentorima katedre za jugoslovensku ili savremenu istoriju.

Neka od novih saznanja srpske istoriografije ušla su u prošloj deceniji u srednjoškolske i udžbenike za osnovnu školu. Istoričari su postali daleko prisutniji u medijima, otvoreno se govori o nekadašnjim tabu temama, u principu javnost je postala svesna novih otkrića i tumačenja srpske istoriografije.

Konačno, 2005. godine zakonski su izjednačena boračka prava ravnogorskog sa partizanskim pokretom. Od 2009. srpski istoričari koji se bave ovom temom bili su članovi dve državne komisije formirane radi utvrđivanja okolnosti i mesta pogubljenja generala Mihailovića, kao i masovnih zločina komunističke vlasti u Srbiji posle septembra 1944. godine. Grob generala Mihailovića nije nađen, a u višegodišnjem radu na dokumentaciji koja je ostala iza srpske OZN-e i UDB-e rekonstruisan je broj likvidiranih lica posle završetka Drugog svetskog rata na 55.000 ljudi poimence. Rad ove druge komisije bio je potpuno javan i imena nastradalih lica su dostupna na njenom internet sajtu.

Konačno, u 2015. godini general Mihailović je sudski rehabilitovan i na taj način je zaokružen proces ispravljanja pravne i istorijske nepravde učinjene prema čoveku koji je vodio od saveznika priznat pokret otpora. Ali i prema svim žrtvama ovog pokreta otpora koje su pale u borbi sa okupatorom ili bili utamničeni u ovdašnjim logorima ili logorima u Trećem rajhu. U procesu rehabilitacije istoričari su se pojavili na sudu u svojstvu svedoka veštaka i dali svoje mišljenje o spornim ratnim događajima. Ipak, to nije prošlo bez problema, jer su dvojica istoričara čiji je nastup pred sudom bio najupečatljiviji po iznesenim podacima i tumačenjima, dobila krivičnu prijavu od strane sedam nevladinih organizacija jula 2013. Tu prijavu je, srećom, odbacio nadležni sud februara 2014.

Već sama ideja da se protiv dvojice istoričara koji su na sud pozvani zvaničnim putem podnese krivična prijava od strane više nevladinih organizacija, a koje plediraju da nose naziv „antifašističke“ i koje se bave „ljudskim pravima", govori o mentalnom sklopu ljudi koji ne podnose da se o pojedinim temama govori na relevantan i kompleksan način. I to o temama 
koje su bile presudne za mnoge ljudske sudbine posle rata, pa čak i danas opterećuju istorijsko sećanje mnogih Srba.

Posle demokratskih promena u Srbiji oktobra 2000. generalno je opalo interesovanje za nove rezultate istoriografije koja se bavi savremenom istorijom i njenim kontroverzama. Dramatična istorija perioda 19912000, ali i potonja okrenutost nacije dnevnom preživljavanju i sveopšta izmena javnog diskursa, uticali su na današnji svojevrstan zamor od istorije i velikih tema u Srbiji. Ipak, svedoci smo da u proteklim godinama određena pitanja u javnosti ponovo dobijaju značajnu pažnju, mada prevashodno $\mathrm{u}$ prostoru politike i medija, a ne u prostoru nauke.

\section{Neka sporna pitanja i tumačenja}

Poslednjih nekoliko godina u javnom diskursu ponovo su oživeli negativni stereotipni pogledi na srpske aktere Drugog svetskog rata (Mihailović, Nedić, Ljotić). Nastali uglavnom u žurnalizmu, ponekad i u politici, pojačani su komentarima ili tumačenjima naših kolega koji u svojim bibliografijama nemaju nijedan naučni rad iz istorije Srbije u Drugom svetskom ratu.

Zabrinjavajuće je to utoliko više što ovakve optužbe nisu postavljale ni posleratne komunističke vlasti koje su sudile pojedinim akterima Nedićeve vlade, a koje su to mogle da učine s obzirom na totalitet posledica njihove pobede i neospornu vlast $\mathrm{u}$ Srbiji. Ranije generacije istoričara koje su otišle $\mathrm{u}$ penziju devedesetih godina, od kojih su neki zaista bili partijski istoričari, svoje radove su zasnivali na arhivskim istraživanjima, a nikako na ovakvim nastupima današnjih njihovih „nastavljača“.

Današnji naslednici starih partijskih istoričara najmanje su vidljivi $\mathrm{u}$ arhivima. Njihovi nastupi su uglavnom medijski, ili na naučnim skupovima, ali bez značajnijih radova ili monografija, bazirani na čitanju zastarelih radova ili samo tumačenju činjenica, interpretaciji ili reinterpretaciji. Jezi$\mathrm{ku}$ proverljivih istorijskih činjenica suprotstavlja se tzv. kultura sećanja koja je, u suštini, bolan i ličan odnos prema prošlosti, uvek naknadna, a nikako relevantan podatak o tome šta se zaista desilo.

Niz spornih pitanja nova srpska istoriografija je razrešila. Da pomenemo samo slučaj generala Mihailovića: heurističkom analizom ustanovili smo neosporne falsifikate kao što su generalova navodna naredba Pavlu Đurišiću od 20. decembra 1941, Mihailovićeva pisma Stepincu ili Paveliću iz proleća 1945, odnosno stavljanje u potpuno pogrešan kontekst Moljevićevih ideja takozvane Velike Srbije i njegove čuvene mape iz 1941. U vreme kada još nije ni čuo za generala Mihailovića. Uvek aktuelno pitanje „kolaboracije“ je glavno mesto sporenja i osnova optužbe za „istorijski revizionizam“.

U toku Drugog svetskog rata stvoren je i „ozakonjen“ pojam kolaboracija kao aktivna saradnja sa okupatorom i angažman u borbi protiv onih 
koji su se suprotstavljali okupatoru (simplifikovano - antifašisti). Kada se, međutim, govori o kolaboraciji treba imati u vidu činjenicu da je ta kolaboracija u raznim zemljama imala različite oblike. I što je važnije, potpuno različite uzroke svoje pojave.

Kolaboracija u Srbiji jeste najteži i najtragičniji primer kolaboracije iz nužde. Osnovna karakteristika te kolaboracije jeste da se pojavljuje kao bezuslovna potreba da se spase narod od uništenja. Pogotovo u toku tragičnog ustanka 1941. godine, gde su drastične nemačke represalije osnov za razumevanje stvaranja Nedićeve vlade i njenih naoružanih odreda, kao i okretanja ravnogorske ustaničke organizacije protiv komunističke, koje će se pretvoriti u bratoubilački rat. Sve u svemu, nemačke masovne represalije $\mathrm{u}$ jesen 1941. čine vododelnicu u odnosima dva ideološki nepomirljiva pokreta -ravnogorskog i komunističkog, kao i osnovu za razumevanje takozvane kolaboracije.

Ali da okrenemo stvari od Nedića i drugih i da se zapitamo: Da li je kolaboracija to što i jugoslovenski, srpski, komunistički pokret ima svoje sedište u Moskvi i što deluje po direktivama dobijenim iz glavnog grada druge, a ne svoje zemlje? Što se komunisti, pa odatle i partizani, na terenu pojavljuju tek posle 22. juna 1941, kada Treći rajh napada na Sovjetski Savez? Što se koriste tuđi simboli, a ne naroda i države kojem se pripada? Što se čitave 1941, ovaj pokret bori u Srbiji sa idejom olakšavanja položaja Crvene armije i očekivanja sovjetskih padobranaca? Što se na terenu uništavaju svi nosioci i elementi bilo kakve građanske vlasti i preslikava sovjetski model vlasti i tretman protivnika?

A šta sa ideologijom u kojoj je učitan građanski rat i sukob klasa kao pokretačka osnova partizanskog pokreta? Šta sa nevođenjem brige o posledicama po narod kome se pripada? Šta je sa problemom da komunizam poznaje samo unutrašnjeg neprijatelja, čime se rukovodi čitava njegova borbena strategija u okupiranoj Srbiji i Jugoslaviji? Kako to da su žrtve komunizma žrtve slobode, a svi drugi žrtve mržnje? Kako to da su partizanske žrtve "leva skretanja“, a žrtve drugih „fašistički teror"? Zašto se sistematski opraštaju partizansko-komunistički zločini, dok se neprekidno stigmatizuju „četnički“, „fašistički“ zločini i prave nategnute paralele sa ratom i zločinima iz 1990-ih?

Ranije optužbe za „kolaboraciju“ na račun srpskih aktera Drugog svetskog rata u okupiranoj Srbiji, od strane ideoloških istoričara i javnosti, sada su pojačane i optužbama za „fašizam“ (suprotstavljen njihovom „antifašizmu“), nekakvom idejnom uticaju na današnju „ekstremnu desnicu“, „klerofašiste“, pa čak i za učešće u holokaustu u Srbiji. Tako se prilično široko shvaćen pojam „antifašizma“ postavlja kao svojevrsni kriterijum istine. Često je jezik izrečenih osuda bliži staljinističkoj ratnoj propagandi 
nego jeziku činjenica. Stoga se o Mihailoviću, Nediću ili Ljotiću i njihovim sledbenicima često ne raspravlja nego optužuje. A oni istoričari koji se bave ovim temama stigmatizuju se za takozvani „revizionizam“.

\section{Optužbe za navodni „revizionizam“ i pojava „antifašizma“}

Šta je takozvana „revizija“ istorije koja se danas često pominje u javnosti Srbije i bivše Jugoslavije? I odmah da suprotstavimo pitanje: da li je napredak istorijske nauke i korespondiranje rezultata novih istraživanja sa pitanjima sadašnjice u stvari revizija? Mi smatramo da nije nikako.

Da li su oni koji su nametnuli ovakav boljševički termin delu svojih kolega koji se bave određenim periodom i temama svesni da je epoha socijalizma prošla? Da je Hladni rat u Evropi završen, da je nestao bipolarni poredak u Evropi? Da je nestala socijalistička Jugoslavija i da su se desili novi ratovi i pojavile nove kontroverzne ličnosti i događaji?

Istorija je, dakle, svojim prirodnim tokom izvršila „reviziju“ na ovom prostoru, a ne nova generacija srpskih istoričara. Zemlje koje su poražene u Drugom svetskom ratu su danas vodeće države u Evropi, Evropskoj uniji i NATO. Šta reći na to? Da li i njih optužiti za reviziju evropskog političkog poretka?

Novim saznanjima i radu $\mathrm{u}$ arhivima, osim termina revizionizam suprotstavlja se i termin „antifašizam“, a iz koga se izvode optužbe za „fašizam“ potom, nešto blaže - „konzervativizam“, odnosno ocena da neko pripada "desnici“. Optužba za „fašizam“ često deluje kao prikladno sredstvo za diskreditaciju ili istorijskih ličnosti i grupa, ili istoričara koji se danas bave njima.

Sa druge strane, antifašizam koji se pojavljuje u javnom diskursu je širok pojam koji uključuje razne vidove: od nastupa nostalgičnih levičarskih intelektualaca preko poraženih komunista do izopačenih seksualnih grupa. Antifašizmu je dat trendovsko-pomodni sadržaj, koji tragične ratne događaje seli u tzv. kulturu sećanja, umetnost, zabavu, ponekad i glamur - što se uočava na pojedinim izložbama ili televizijskim emisijama u kojima se artikuliše ovakav stav.

Postmoderno relativizovanje svih činjenica, korišćenje netačnih podataka i zanatsko prenebregavanje novih dostignuća istorijske nauke nadovezuje se na zastarele domete propartizanske istoriografije iz ranih decenija Titove Jugoslavije.

Umesto da se komunizam osudi kao jedno od najvećih zala koje je pogodilo srpsku savremenu istoriju po ostavljenim posledicama, ostaci komunista i njihovi postmodernistički naslednici i dalje žele da utiču na kolektivno mišljenje, a po ustaljenoj staljinističkoj praksi da sve koji im se suprotstave odmah proglase za fašiste. 
Šta je razlog ovom ideološkom talasu? Neuspeh demokratskih promena i tranzicije u Srbiji posle 2000. godine kao i nejasan ideološki stav demokratskih vlasti prema komunističkom nasleđu, samo su pogodovali rastu „antifašizma“, a u istorijskoj nauci optužbama za „revizionizam“. To je prostor gde se komunizam preselio u umiveni građanski antifašizam, prikladan savremenim „vrednostima“ dela zapadne civilizacije.

Smatramo da realno kontekstualizovanje istorijskih događaja može valjano da opiše prošlost, ali i ukaže na sadašnjost $u$ ispravnom kontekstu. Više kao pouka, a ne izvor odakle se zahvataju fragmenti za gorljivo korišćenje u dnevnoj politici. Umesto optužbi, kojima su skloni levičarski intelektualci, više smo za dijalog o činjenicama i za raspravu o problemima iz prošlosti.

Konačno, u čemu je svrha istorijske nauke ako ne da novim istraživanjima pomeri granice saznanja, razreši istorijske dileme i nedoumice i ponudi adekvatne odgovore koje traži sadašnjost? 